Didaktik : Jurnal Pendidikan, ISSN : 2477-5673, E-ISSN : 2614-722X

Sekolah Tinggi Keguruan dan IImu Pendidikan Subang

Volume V Nomor 1, Juni 2019

\title{
PENGARUH MANAJEMEN KEUANGAN DAN MANAJEMEN SARANA \\ PRASARANA TERHADAP MUTU PROSES PEMBELAJARAN PADA \\ SEKOLAH DASAR DI WILAYAH UNIT PENGAWAS TINGKAT DINAS \\ (UPTD) PENDIDIKAN BALONGAN KABUPATEN INDRAMAYU
}

\author{
Koridin \\ Wresni Pujiyati
}

\begin{abstract}
This study aims to determine the effect of financial management and infrastructure management on the quality of the learning process in elementary schools in the area of UPTD Education Balongan. The method used descriptive analysis uses a quantitative approach. Data analysis techniques using regression analysis techniques. The findings of this study are financial management, facilities and infrastructure management and the quality of the learning process have been carried out well; (1) Financial management has a significant effect on the quality of the learning process (2) Infrastructure management has an influence on the quality of the learning process and shows a significant relationship, (3) Financial management and infrastructure management together have a significant effect on the quality of the learning process teachers are expected to improve and create a learning atmosphere. "PAIKEM", schools are expected to be able to manage financially efficiently and efficiently, schools are expected to have a place to store goods / warehouses that are still suitable for use.
\end{abstract}

Keywords: Financial management, infrastructure management and the quality of the learning process.

\section{ABSTRAK}

Penelitian ini bertujuan untuk mengetahui pengaruh antara menajemen keuangan dan manajemen sarana prasarana terhadap mutu proses pembelajaran pada sekolah dasar di wilayah UPTD Pendidikan Balongan. Metode yang digunakan deskriptif analisis menggunakan pendekatan kuantitatif. Teknik Analisis data menggunakan teknik analisis regresi. Temuan penelitian ini adalah manajemen keuangan, manajemen sarana prasarana dan mutu proses pembelajaran telah terlaksana dengan baik; (1) Manajemen keuangan berpengaruh secara signifikan terhadap mutu proses pembelajaran (2) Manajemen sarana prasarana memberikan pengaruh terhadap mutu 
proses pembelajaran dan menunjukan hubungan yang signifikan, (3) Manajemen keuangan dan manajemen sarana prasarana secara bersamasama berpengaruh secara signifikan terhadap mutu proses pembelajaran guru di harapkan dapat meningkatkan dan menciptakan suasana pembelajaran yang. "PAIKEM", sekolah diharapkan dapat mengelola keungan secara efetif dan efesien, sekolah diharapkan memiliki tempat penyimpanan barangbarang/gudang yang masih layak pakai.

Kata kunci : Manajemen keuangan, manajemen sarana prasarana dan mutu proses pembelajaran.

\section{A. Pendahuluan}

Input pendidikan dinyakan bermutu jika siap berproses, proses pendidikan bermutu apabila mampu menciptakan suasana yang PAIKEM (pembelajaran aktif, inovatif, kreatif, efektif dan menyenangkan) output pendidikan dikatakan bermutu jika hasil belajar akademik maupun non akademik siswa tinggi. Outcome dinyatakan bermutu apabila lulusan terserap di dunia kerja, gaji wajar, semua pihak mengikuti kebebasan lulusan dan merasa puas. (Husaini Usman, 2006).

"Kuikulum dan program pengajaran, tenaga kependidikan, kesiswaan, keuangan, sarana prasarana pendidikan, pengelolaan hubungan sekolah dan masyarakat, serta manajemen khusus lembaga pendidikan". (Mulyasa, 2003)

"fungsi dari manajemen keuangan dalam pendidikan adalah untuk melaksanakan kegiatan agar suatu tujuan tercapai dengan efektif dan efisien". (Tim Dosen UPI, 2009) ,"Mutu adalah sebuah filosofis dan metodologis yang membantu institusi untuk merencanakan perubahan dan mengatur agenda dalam menghadapi tekanan-tekanan eksternal yang berlebihan". (Edward Sallis, 2006)

,"Mutu mengandung makna derajat keunggulan suatu produk atau hasil kerja, baik berupa barang dan jasa". (Sudarwan Danim, 2007)

"Mutu adalah pemenuhan terhadap kebutuhan stakeholder, bersistem pencegahan, mempunyai standar tanpa cacat dan mempunyai ukuran harga ketidakpuasan". (Toni Bush, 2006) Mutu input, output dan outomes. Input pendidikan dinyatakan bermutu jika siap berproses, proses pendidikan bermutu apabila mampu menciptakan suasana yang PAIKEM ( pembelajaran aktif, inovatif, kreatif, efektif dan menyenangkan) output pendidikan dikatakan bermutu jika hasil belajar 
akademik maupun non akademik siswa tinggi. Outcome dinyatakan bermutu apabila lulusan terserap di dunia kerja, gaji wajar, semua pihak mengikuti kebebasan lulusan dan merasa puas. (Husaini Usman, 2006). Sedangkan pengertian pembelajaran menurut Corey' adalah suatu proses dimana lingkungan seseorang secara sengaja dikelola untuk memungkinkan ia turut serta dalam tingkah laku tertentu dalam kondisikondisi khusus atau menghasilkan respon terhadap situasi tertentu'. (Sagala,2003)

Ricky W. Griffin menyatakan bahwa manajemen adalah seperangkat aktivitas yang meliputi perencanaan dan pengambilan keputusan, pengorganisasian, pengarahan dan pengawasan yang dilaksanakan langsung oleh suatu sumber daya organisasi (manusia, uang, benda-benda fisik, dan informasi. Manajemen adalah aktivitas yang prinsipnya untuk membuat suatu perbedaan dalam hal bagaimana organisasi lebih baik melayani orang yang telah di pengaruhi oleh mereka, sebagai bentuk tanggung jawab social yang memuaskan, maka hal itu tergantung kepada keluasan tingkat manajemen. ((Maisah, 2013)

$$
\text { Pengertian keuangan }
$$

adalah ilmu dan seni dalam mengelola uang, yang mempengaruhi kehidupan setiap orang dan setiap organisasi, Keuangan berhubungan dengan proses, lembaga, pasar dan instrumen yang terlihat dalam transfer uang, diantara individu maupun antara bisnis dan pemerintah. (Ridwan dan Inge Barlian, 2003)

Meurut Depdiknas Ditjen Dikdasmen 2000 Manajemen keuangan diartikan sebagai tindakan

pengurusan/ketatausahaan

keuangan yang meliputi pencatatan, perencanaan, pelaksanaan, pertanggungjawaban dan pelaporan. Manajemen keuangan sekolah merupakan rangakaian aktivitas mengatur keuangan keuangan sekolah mulai dari perencanaan, pembukuan, pembelajaan, pengawasan dan pertanggungjawaban sekolah'. (Jamal Ma'mur Asmani, 2012) 


$$
\text { Maysarah menjelaskan }
$$

bahwa: Manajemen keuangan adalah suatu proses melakukan kegiatan mengatur keuangan dengan menggerakkan tenaga orang lain. Kegiatan ini dapat dimulai dari perencanaan, pengorganisasian, pelaksanaan sampai dengan pengawasan. Dalam manajemen keuangan di sekolah tersebut dimulai dengan perencanaan anggaran sampai dengan pengawasan dan pertanggung jawaban keuangan. (Sulistyorini, 2009)

Ada tiga tahapan dalam manajemen keuangan pendidikan yaitu meliputi: Pertama perencanaan keuangan yaitu yang dengan istilah lain disebut dengan budgeting yang merupakan kegiatan mengkoordinasi semua dana tersedia untuk mencapai tujuan yang di inginkan secara efektif dan sistematis, tahap kedua yaitu pelaksanaan anggaran (implementation) yang merupakan pelaksanaan kegiatan berdasarkan rencana yang telah dibuat pada proses perencanaan sebelumnya, setelah tahapan perencanaan dan pelaksanaan dilakukan maka tahapan selanjutnya yaitu evaluasi yang merupakan proses evaluasi terhadap pencapai tujuan yang telah di tetapkan. (E. Mulyasa, 2002)

Arikunto dan Yuliana menyatakan: Manajemen keuangan dalam pengertian umum keuangan, kegiatan pembiayaan meliputi tiga hal, yakni budgeting atau penyusunan anggaran, accounting atau pembukuan dan auditing atau pemeriksaan, sementara Wijaya mengartikan manajemen keuangan merupakan manajemen terhadap fungsi-fungsi keuangan, sedangkan fungsi keuangan merupakan kegiatan yang utama yang harus dilakukan oleh mereka yang bertanggungjawab dalam bidang tertentu. (Hermino Agustinus, 2013) Sarana pendidikan adalah perlengkapan yang secara langsung dipergunakan untuk proses pendidikan seperti meja, kursi, kelas dan media pengajaran. Sedangkan prasarana pendidikan adalah fasilitas yang secara tidak langsung menunjang jalannya proses pendidikan seperti halaman, 
kebun, dan taman". (Sri Minarti, 2011)

\section{Manajemen}

sarana

prasarana sebagai suatu proses

kerjasama pendayagunaan semua

perlengkapan pendidikan secara

efektif dan efesien meliputi:

perencanaan,

pengadaan,

pendistribusian,

penggunaan,

pemeliharaan,

iventaris,

penghapusan". (Ibrahim Bafadal, 2010)

$$
\text { Manajemen }
$$

sarana

prasarana adalah kegiatan yang mengatur untuk mempersiapkan segala peralatan/pendidikan.

Manajemen sarana prasarana dibutuhkan untuk membantu kelancaran proses belajar mengajar. Sarana prasarana adalah semua benda bergerak dan tidak bergerak yang dibutuhkan untuk menunjang kegiatan belajar mengajar, baik secara langsung maupun tidak langsung. Manajemen sarana prasarana merupakan keseluruhan proses perencanaan, pengadaan, pendayagunaan, dan pengawasan. Sarana dan prasarana yang digunakan agar tujuan pendidikan dapat dicapai dengan efektif dan efesien. Kegiatan sarana prasarana meliputi:

(1)

perencanaan

kebutuhan

(2) pengadaan

penyimpanan

penginventarisasian

pemeliharaan dan (6) penghapusan sarana dan prasarana pendidikan. (Rohiat, 2010)

"menyebutkan bahwa kegiatan dalam manajemen sarana dan prasarana pendidikan meliputi: perencanaan kebutuhan, pengadaan, penyimpanan, inventarisasi, pemeliharaan, penghapusan dan pengawasan". (Soetjipto dan Raflis Kosasi, 2007)

\section{B. Metode Penelitian}

Penelitian ini menggunakan pendekatan kuantitatif. Populasi penelitian ini merupakan populasi homogen yaitu seluruh guru sekolah dasar yang berstatus PNS sejumlah 119 orang di Wilayah UPTD Pendidikan Kecamatan Balongan Kabupaten Indramayu. Melalui penelitian ini penulis mengambil sampel sebanyak $25 \%$ atau sebanyak 54 guru PNS. 
Didaktik : Jurnal Pendidikan, ISSN : 2477-5673, E-ISSN : 2614-722X

Sekolah Tinggi Keguruan dan IImu Pendidikan Subang

Volume V Nomor 1, Juni 2019

C. Hasil Penelitian dan

Pembahasan

untuk menguji signifikasi korelasi antar variabel dalam penelitian ini, yaitu variabel manajemen keuangan (X1) dengan variabel mutu proses pembelajaran $(\mathrm{Y})$, variabel manajemen sarana prasarana (X2) dengan mutu proses pembelajaran (Y), serta variabel manajemen keuangan (X1) dan variabel manajemen sarana prasarana (X2), secara bersamasama dengan variabel mutu proses pembelajaran $(\mathrm{Y})$ dilakukan dengan menggunakan formula momen hasil kali pearson yang diolah melalui prosedur correlation pearson two tail pada program SPSS statistics 16. Hasil yang diperoleh berupa harga $r$ dari perhitungan tersebut selanjutnya dijadikan sebagai penentu nilai Fhitung yang akan dikonsultasikan dengan nilai Ftabel pada df $=1 / 37$ dengan taraf signifikansi $95 \%$, yaitu sebesar 3,94.

Tabel 1

Persamaan Regresi X1 Terhadap Y

Coefficients $^{a}$

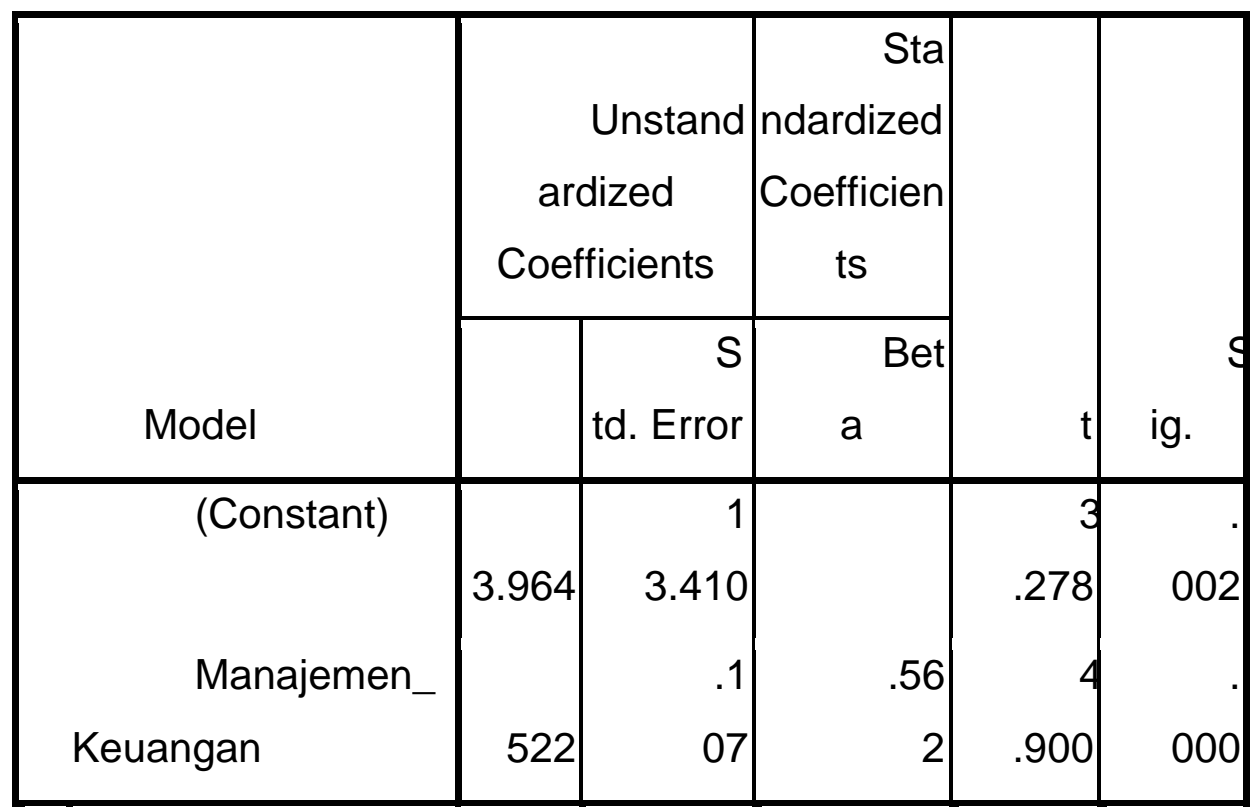

a. Dependent Variable:

Mutu_Proses_Pembelajaran 
Didaktik : Jurnal Pendidikan, ISSN : 2477-5673, E-ISSN : 2614-722X

Sekolah Tinggi Keguruan dan IImu Pendidikan Subang

Volume V Nomor 1, Juni 2019

Berdasarkan tabel diatas persamaan regresi $\mathrm{X} 1$ terhadap $\mathrm{Y}$ adalah $\hat{Y}=43,964+0,522 \times 1$. Dengan persamaan regresi tersebut dapat di interpretasikan bahwa jika variabel manajemen keuangan (X1) dengan mutu proses pembelajaran (Y) diukur dengan instrumen yang dikembangkan dalam penelitian ini maka setiap perubahan skor manajemen keuangan sebesar satu satuan dapat diestimasikan skor mutu proses pembelajaran akan berubah sebesar 0,522 satuan pada arah yang sama.
Kriteria

pengujian persamaan regresi adalah tolak $\mathrm{HO}$ jika probabilitas lebih kecil dari alpha $=0,05$. Berdasarkan tabel diatas nilai probabilitas sebagaimana ditunjukan pada kolom sig/significance adalah 0.02 sehingga nilai probabilitas jauh lebih kecil dari 0.05. Dapat disimpulkan bahwa koefisien regresi signifikan, atau manajemen keuangan secara signifikan berpengaruh terhadap mutu proses pembelajaran.

Tabel 2

Persamaan Regresi X2 terhadap YCoefficients ${ }^{\mathrm{a}}$

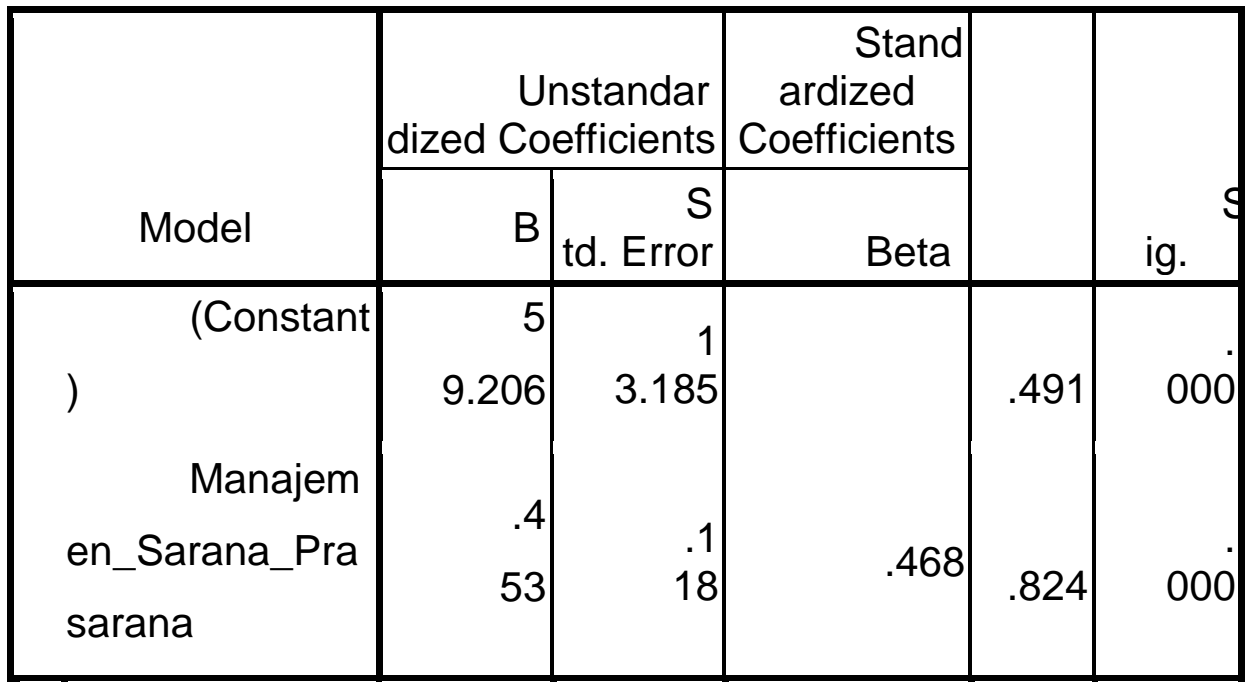

a. Dependent Variable: Mutu_Proses_Pembelajaran

Berdasarkan tabel diatas adalah $\hat{Y}=59,206+0,453$ X2 persamaan regresi $\mathrm{X} 2$ terhadap $\mathrm{Y}$ Dengan persamaan regresi 
Didaktik : Jurnal Pendidikan, ISSN : 2477-5673, E-ISSN : 2614-722X

Sekolah Tinggi Keguruan dan IImu Pendidikan Subang

Volume V Nomor 1, Juni 2019

tersebut dapat di interpretasikan bahwa jika variabel manajemen sarana prasarana (X2) dengan mutu proses pembelajaran $(\mathrm{Y})$ diukur dengan instrumen yang di kembangkan dalam penelitian ini, maka setiap perubahan skor manajemen sarana prasarana sebesar satu satuan dapat diestimasikan skor mutu proses pembelajaran akan berubah sebesar 0,453 satuan pada arah yang sama.

Makna persamaan regresi didasarkan pada hasil perhitungan dengan menggunakan bantuan SPSS 16. Kriteria pengujian persamaan regresi adalah Ho. ditolak jika probabilitas lebih kecil dari alpha $=0,05$. Berdasarkan tabel diatas nilai probabilitas sebagaimana ditunjukan pada kolom sig/significance adalah 0.000 sehingga nilai probabilitas jauh lebih kecil dari 0,05. Dapat disimpulkan koefisien regresi signifikan, atau manajemen sarana prasarana berpengaruh secara signifikan terhadap mutu proses pembelajaran.

Tabel 3

Persamaan Regresi X1, X2 Terhadap Y

Coefficients $^{a}$

\begin{tabular}{|c|c|c|c|c|c|c|c|c|}
\hline \multirow[b]{2}{*}{ Model } & \multicolumn{2}{|c|}{$\begin{array}{c}\text { Unstandardiz } \\
\text { ed } \\
\text { Coefficients }\end{array}$} & $\begin{array}{c}\text { Standardiz } \\
\text { ed } \\
\text { Coefficient } \\
\text { s }\end{array}$ & & & \multicolumn{3}{|c|}{ Correlations } \\
\hline & & $\begin{array}{l}\text { Std. } \\
\text { Error }\end{array}$ & Beta & & ig. & $\begin{array}{c}\text { ero- } \\
\text { orde } \\
r\end{array}$ & artial & Part \\
\hline tant) & 8.651 & 4.626 & & .959 & 056 & & & \\
\hline $\begin{array}{l}\text { Manajem } \\
\text { en_Keua } \\
\text { ngan }\end{array}$ & 410 & 114 & .442 & .590 & 001 & 562 & 449 & .397 \\
\hline $\begin{array}{l}\text { Manajem } \\
\text { en_Sara } \\
\text { na_Pras } \\
\text { arana }\end{array}$ & 266 & 119 & .275 & .235 & 030 & 468 & 299 & .247 \\
\hline
\end{tabular}

a. Dependent Variable: Mutu_Proses_Pembelajaran 
Berdasarkan data pada tabel diatas, persamaan regresi $Y$ atas X1 dan X2 adalah : $\hat{Y}=28,651+$ $0,410 X 1+0,266$ X2 .Dengan persamaan regresi tersebut dapat di interpretasikan bahwa jika variabel manajemen keuangan (X1) dan variabel manajemen sarana prasarana (X2) dengan mutu proses pembelajaran ( $Y$ ) diukur dengan instrumen yang dikembangkan dalam penelitian ini, maka setiap perubahan skor manajemen keuangan dan manajemen sarana prasarana sebesar satu satuan dapat diestimasikan skor mutu proses pembelajaran akan berubah sebesar 0,410 satuan $X 1$ dan 0,266 satuan X2 pada arah yang sama.

Makna persamaan regresi didasarkan pada hasil perhitungan dengan menggunakan bantuan SPSS 16. Kriteria pengujian persamaan regresi adalah $\mathrm{Ho}$ diterima jika probabilitas lebih besar dari alpha $=0,05$. Berdasarkan tabel diatas nilai probabilitas sebagaimana ditunjukan pada kolom sig/significance adalah 0,56 sehingga nilai probabilitas lebih besar dari 0,05. Dapat disimpulkan koefisien regresi signifikan, atau manajemen keuangan dan manajemen sarana prasarana berpengaruh secara signifikan terhadap mutu proses pembelajaran.

Pertama, Kontribusi Manajemen Keuangan terhadap Mutu Proses Pembelajaran pada Sekolah Dasar di Wilayah UPTD Pendidikan Balongan Kabupaten Indramayu. Manajemen keuangan merupakan salah satu substansi manajamen sekolah yang akan turut menentukan berjalannya kegiatan pendidikan disekolah. Sebagaimana yang terjadi di substansi manajemen pendidikan pada umumnya, kegiatan manajemen keuangan dilakukan melalui proses perencanaan, pengorganisasian, pengarahan, pengkoordinasian, pengawasan atau pengendalian..

Menurut

Maysarah

(Sulistyorini, 2009:130) menjelaskan bahwa:

Manajemen keuangan adalah suatu proses melakukan kegiatan mengatur keuangan dengan menggerakkan tenaga 
orang lain. Kegiatan ini dapat dimulai dari perencanaan, pengorganisasian, pelaksanaan sampai dengan pengawasan. Dalam manajemen keuangan di sekolah tersebut dimulai dengan perencanaan anggaran sampai dengan pengawasan dan pertanggung jawaban keuangan.

Komponen

keuangan/pembiayaan pada suatu sekolah merupakan komponen produksi yang menentukan terlaksananya kegiatan-kegiatan proses belajar mengajar di sekolah bersama komponen-komponen lain. Menurut Tim Dosen UPI (2009:92), "fungsi dari manajemen keuangan dalam pendidikan adalah untuk melaksanakan kegiatan agar suatu tujuan tercapai dengan efektif dan efisien"..

\section{Berdasarkan} hasil perhitungan dengan SPSS statistic 16. Nilai korelasi yang diperoleh untuk $X 1$ dengan $Y$ sebesar 0.000 berarti terdapat hubungan yang cukup kuat antara manajemen keuangan dengan mutu proses pembelajaran, uji signifikasi untuk $\mathrm{X} 1$ dengan $\mathrm{Y}$ di peroleh variabel manajemen keuangan (X1) mempunyai nilai signifikan 0.000 . yang lebih kecil dari nilai probabilitas 0.05. Maka Ho ditolak dan $\mathrm{Ha}$ diterima, yang artinya signifikan. Terbukti bahwa manajemen keuangan mempunyai hubungan yang signifikan terhadap mutu proses pembelajaran. Besarnya koefisien determinasi variabel manajemen keuangan (X1) terhadap mutu proses pembelajaran ( $\mathrm{Y}$ ) adalah sebesar 0,316 atau 31,6 \%. Artinya mutu proses pembelajaran dipengaruhi oleh variabel manajemen keuangan sebesar 31,6\% sedangkan sisanya di pengaruhi oleh faktor lain.

Kedua, Kontribusi Manajemen Sarana Prasarana Terhadap Mutu Proses Pembelajaran pada Sekolah Dasar di Wilayah UPTD Pendidikan Balongan Kabupaten Indramayu. Menurut Sulistyorini (2009:11),"manajemen adalah kegiatan seseoarang dalam mengatur organisasi, lembaga atau sekolah yang bersifat manusia maupun non manusia, sehingga tujuan organisasi, lembaga atau sekolah dapat tercapai secara efektif dan efesien". Artinya untuk 
menciptakan sekolah yang bersih, rapi, indah dan menyenangkan baik bagi guru maupun bagi siswa sehingga akan betah berada di sekolah, semua tidak lepas dari fungsi manajemen sarana prasarana, karena manajemen sarana prasrana dapat memberikan kontribusi yang optimal pada jalannya proses pendidikan di sekolah. Rohiat (2010:26) menyatakan bahwa:

Manajemen

sarana

prasarana adalah kegiatan yang mengatur untuk mempersiapkan segala peralatan/pendidikan. Manajemen sarana prasarana dibutuhkan untuk membantu kelancaran proses belajar mengajar. Sarana prasarana adalah semua benda bergerak dan tidak bergerak yang dibutuhkan untuk menunjang kegiatan belajar mengajar, baik secara langsung maupun tidak langsung. Manajemen sarana prasarana merupakan keseluruhan proses perencanaan, pengadaan, pendayagunaan, dan pengawasan. Sarana dan prasarana yang digunakan agar tujuan pendidikan dapat dicapai dengan efektif dan efesien. Kegiatan sarana prasarana

meliputi: (1) perencanaan

kebutuhan (2) pengadaan (3)

penyimpanan

penginventarisasian

pemeliharaan dan (6) penghapusan sarana dan prasarana pendidikan. . Dalam penelitian ini, nilai probabilitas sebagaimana ditunjukkan pada kolom Sig /Significance adalah 0.000 sehingga nilai probabilitas jauh lebih kecil dari 0.05. Dapat disimpulkan koefisien regresi signifikan, atau manajemen sarana prasarana berpengaruh secara signifikan terhadap mutu proses pembelajaran. Berdasarkan hasil pengolahan data dapat di ketahui besarnya koefisien determinasi variabel manajemen sarana prasarana (X2) terhadap variabel mutu proses pembelajaran (Y) adalah sebesar 0,219 atau 21,9 \%. Artinya mutu proses pembelajaran dipengaruhi oleh variabel manajemen sarana prasarana sebesar 21,9 \%, sedangkan sisanya dipengaruhi oleh faktor lain.

Ketiga, Kontribusi antara Manajemen Keuangan dan 
Manajemen Sarana Prasarana

Terhadap

Mutu

Proses

Pembelajaran pada Sekolah Dasar di Wilayah UPTD Pendidikan Balongan Kabupaten Indramayu. Dalam peningkatkan mutu pendidikan dapat dipengaruhi oleh faktor input pendidikan dan faktor proses manajemen pendidikan. Input pendidikan adalah segala sesuatu yang harus tersedia karena dibutuhan untuk berlangsungnya proses. Untuk meningkatkan mutu proses pembelajaran tentunya tidak hanya komponen guru, peserta dan kurikulum saja, kehadiran manajemen keuangan dan manajemen sarana dan prasarana sudah menjadi keharusan dalam mencapai

keberhasilan pembelajaran. Karena komponen keuangan/pembiayaan pada suatu sekolah merupakan komponen produksi yang menentukan terlaksananya kegiatan-kegiatan proses belajar mengajar di sekolah bersama komponen-komponen lain. Menurut Tim Dosen UPI (2009:92), "fungsi dari manajemen keuangan dalam pendidikan adalah untuk melaksanakan kegiatan agar suatu tujuan tercapai dengan efektif dan efisien". Dan untuk menciptakan sekolah yang bersih, rapi, indah dan menyenangkan baik bagi guru maupun bagi siswa sehingga akan betah berada di sekolah, tidak lepas dari peranan manajemen sarana prasarana.

Besarnya korelasi antara variabel manajemen keuangan dan manajemen sarana prasarana dengan secara bersama-sama terhadap mutu proses pembelajaran yang dihitung dengan koefisien korelasi adalah 0,562 . Dengan demikian dapat di interprestasikan bahwa hubungan antara manajemen keuangan dan manajemen sarana prasarana terhadap mutu proses pembelajaran tergolong cukup tinggi.

Berdasarkan hasil analisis data dapat diketahui besarnya koefisien determinasi variabel manajemen keuangan (X1) dan manajemen sarana prasarana (X2) secara bersama-sama terhadap variabel mutu proses pembelajaran (Y) adalah sebesar 0,377 atau 37,7 $\%$ Artinya mutu proses pembelajaran dipengaruhi oleh variabel manajemen keuangan dan 
Didaktik : Jurnal Pendidikan, ISSN : 2477-5673, E-ISSN : 2614-722X

Sekolah Tinggi Keguruan dan IImu Pendidikan Subang

Volume V Nomor 1, Juni 2019

variabel manajemen sarana
prasarana secara bersama-sama
sebesar $37,7 \%$, sedangkan
sisanya dipengaruhi oleh faktor
lain.

\section{Kesimpulan}

Berdasarkan analisis data dan pengujian hipotesis dapat diambil kesimpulan sebagai berikut:

1. Manajemen

keuangan

berpengaruh secara signifikan terhadap mutu proses pembelajaran pada sekolah dasar di wilayah UPTD Pendidikan Balongan Kabupaten Indramayu, besarnya determinansi variabel manajemen keuangan terhadap variabel mutu proses pembelajaran (Y) adalah sebesar 0,316 atau 31,6\% artinya mutu proses pembelajaran di pengaruhi oleh variabel manajemen keuangan sebesar $31,6 \%$

2. Manajemen sarana prasarana berpengaruh secara signifikan terhadap mutu proses pembelajaran pada sekolah dasar di wilayah UPTD
Pendidikan

Balongan

Kabupaten Indramayu.

Besarnya koefisien determinasi variabel manajemen sarana prasarana (X2) terhadap variabel mutu proses pembelajaran (Y) adalah sebesar 0,219 atau 21,9\%. Artinya mutu proses pembelajaran dipengaruhi oleh variabel manajemen sarana prasarana sebesar $21,9 \%$.

3. Manajemen keuangan dan manajemen sarana prasarana secara bersama-sama berpengaruh secara signifikan terhadap mutu proses pembelajaran pada sekolah dasar di wilayah UPTD Pendidikan Balongan Kabupaten Indramayu. Besarnya koefisien determinasi variabel manajemen keuangan (X1) dan manajemen sarana prasarana (X2) secara bersama-sama terhadap variabel mutu proses pembelajaran ( $\mathrm{Y}$ ) adalah adalah sebesar 0,377 atau 37,7 \%. Artinya mutu proses pembelajaran dipengaruhi oleh variabel manajemen keuangan dan variabel manajemen sarana 
Didaktik : Jurnal Pendidikan, ISSN : 2477-5673, E-ISSN : 2614-722X

Sekolah Tinggi Keguruan dan IImu Pendidikan Subang Volume V Nomor 1, Juni 2019

prasarana secara bersamasama sebesar $37,7 \%$, sedangkan sisanya dipengaruhi oleh faktor lain.

\section{DAFTAR PUSTAKA}

Akdon, Sahlan Hadi (2005), Aplikasi Statistika dan Metode Penelitian untuk Administrasi dan Manajemen, Bandung: Dewa Ruchi.

Atmodiwiro, S (2000), Manajemen Pendidikan Indonesia, Jakarta: Ardadizya Jaya.

Barnawi, M. A (2012), Manajemen

Sarana dan Prasarana

Sekolah, Yogyakarta: Ar-Ruzz Media

Bush, Tony dan Mariannecoleman (2006), Leadership dan Srategic Manajement In Education Manajemen Strategis Kepemimpinan Pendidikan, Terjemahan Fahruroji, Jogyakarta: IRCISOD

Dalyono (2009), Psikologi

Pendidikan, Jakarta: Rineke Cipta.

Daryanto (2008), Administrasi

Pendidikan, Jakarta: Rineka Cipta.
Direktorat Tenaga Kependidikan 200, Manajemen Keuangan Sekolah

Dzamarah, S.B.(2011), Psikologi Belajar, Jakarta: Rineke Cipta.

E. Mulyasa (2002:49), Manajemen Berbasis Sekolah, Strategi dan Implementasi, Bandung: PT. Remaja Rosdakarya

Edward Sallis (2006), Total Quality Management In Education, Jogjakarta : IRCiSoD.

George R. Terry (2003), Prinsip-

Prinsip Manajemen, Jakarta:

PT. Bumi Aksara.

Gunawan, Beni (2000), Diklat Metodologi Penelitian, Program Pascasarjana, Jakarta.

Hermino, (2013), Asesmen Kebutuhan Organisasi Persekolahan Timjauan Prilaku Organisasi Menuju Comprehensive Multilevel Planning, Jakarta: PT. Gramedia Pustaka Utama.

Ibrahim B (2003), Manajemen Perlengkapan Sekolah Teori dan Aplikasinya, Jakarta: PT Bumi Aksara. 
Didaktik : Jurnal Pendidikan, ISSN : 2477-5673, E-ISSN : 2614-722X

Sekolah Tinggi Keguruan dan IImu Pendidikan Subang

Volume V Nomor 1, Juni 2019

Asmani, J.M. (2012), Tips Aplikasi

Manajemen

Sekolah,

Jogjakarta: Diva Press.

Kurniadin, D.Machali, I, (2013),

ManajemenPendidikan:

Konsep dan Prinsip

Pengelolaan Pendidikan,

Jogjakarta: Ar-Ruzz Media.

Sumayang, L (2003), Manajemen

Produksi dan Operasi, Jakarta

: Salemba Empat.

Maisah (2013), Manajemen

Pendidikan, Jakarta: Gaung

Persada Press Group.

Maryaeni (2005), Metode Penelitian

Kebudayaan, Malang: Bumi

Aksara

Mulyasa, E (2002), Manajemen

Berbasis Sekolah, Bandung:

Remaja Rosda Karya

Mulyasa, E (2007), Manajemen

Berbasis Sekolah, Bandung:

Remaja Rosdakarya.

Nanang Fattah (2011), Landasan

Manajemen Pendidikan,

Bandung: PT. Remaja

Rosdakarya.

Peraturan Menteri Pendidikan

Nasional No.24 tahun 2007,

Tentang Standar Sarana dan

Prasarana.
Peraturan Menteri Pendidikan

Nasional Republik Indonesia

Nomor 41 Tahun 2007, tentang Standar Proses Untuk Satuan Pendidikan Dasar dan Menengah.

Peraturan Pemerintah No. 19

Tahun 2005 Tentang Standar Nasional Pendidikan, Jakarta:

Depdiknas.

Sunjaya, R.S. dan Barlian, I. (2003), Manajemen

Keuangan Satu, Jakarta:

Literata Lintas Media.

Rohiat (2010), Manajemen Sekolah, Bandung: PT. Refika Aditama.

Sagala, S. (2003), Konsep dan Makna Pembelajaran, Bandung: Alfabeta.

Shadily, H. (2005), Kamus Inggris Indonesia, Jakarta: PT. Gramedia.

Soetjipto, R.K., (2007), Profesi Keguruan, Jakarta: Rineka Cipta.

Sri Minarti (2011), Manajemen Sekolah: Mengelola Lembga Pendidikan Secara Mandiri, Yogyakarta: Ar-Ruzz Media 
Sudarwan Danim (2007), Visi Baru

Manajemen Sekolah, Jakarta

: Bumi Aksara.

Sugiono (2009), Metode Penelitian

Kuantitatif Kuantitatif $R$ dan $D$,

Bandung: Afabeta

Sukmadinata, Nana Syaodih

(2012), Metode Penelitian

Pendidikan, Bandung:

Remaja Rosdakarya.

Sulistyorini (2009), Manajemen

Pendidikan Islam,

Yogyakarta: Teras.

Suryabrata (2003), Metodelogi

Penelitian, Rajawali Pers:

Jakarta.

Susilo (2007), Manajemen Sumber

Daya Manusia, Yogyakarta:

BPFE

Syah, M., (2004), Psikologi

Pendidikan dengan

Pendekatan Baru, Bandung:

Remaja Rosdakarya.

Tim Dosen Administrasi Pendidikan

Universitas Pendidikan

Indonesia (2009) Manajemen

Pendidikan, Bandung:

Alfabeta. 